\title{
Penerapan Algoritma C4.5 Untuk Prediksi Loyalitas Nasabah PT Erdika Elit Jakarta
}

\author{
Khotibul Umam ${ }^{1}$, Diah Puspitasari ${ }^{2}$, Acmad Nurhadi ${ }^{3}$ \\ ${ }^{1}$ Program Studi Sistem Informasi, STMIK Nusa Mandiri, Jakarta, Indonesia \\ ${ }^{2}$ Program Studi Sistem Informasi, Universitas Bina Sarana Informatika, Indonesia \\ ${ }^{3}$ Program Studi Teknologi Komputer, Universitas Bina Sarana Informatika, Indonesia \\ Email: ${ }^{1}$ khotibulumam51@gmail.com, ${ }^{2}$ diah.puspitasari@bsi.ac.id, ${ }^{3}$ achmad.ahh@bsi.ac.id
}

\begin{abstract}
Abstrak-Algoritma C4.5 merupakan kelompok algoritma decision tree. Algoritma ini mempunyai input berupa training samples dan samples. Sedangkan samples merupakan field-field data yang nantinya akan kita gunakan sebagai parameter dalam melakukan klasifikasi data. Dari variabel frekuensi transaksi perusahaan dapat melihat nasabah mana yang loyal terhadap perusahaan berdasarkan data historis transaksi nasabah, namun masih ada beberapa variabel yang membuat nasabah loyal terhadap perusahaan. Variabel - variabel tersebut ialah usia, gender nasabah, gender sales perusahaan, latar belakang pendidikan, frekuensi transaksi nasabah. Perusahaan mengetahui bagaimana memprediksi nasabah yang akan loyal terhadap perusahaan berdasarkan pengalaman dari beberapa variabel diatas, namun perusahaan tidak mengetahui variabel yang paling berpengaruh dalam penilaian nasabah yang loyal karena dari beberapa variabel diatas tidak saling terhubung dan belum pasti kalau satu variabel dapat membuat keputusan apakah nasabah tersebut loyal. Berdasarkan pohon keputusan yang telah dibuat atribut yang paling berpengaruh terhadap loyalitas nasabah adalah latar belakang pendidikan karena memiliki nilai gain yang paling tinggi yaitu 1.545292721 dan sebagai akar dari pohon keputusan sedangkan gender nasabah tidak terlalu berpengaruh terhadap loyalitas nasabah karena selalu berada pada node terakhir dengan nilai gain yaitu 0,623919119.
\end{abstract}

Kata Kunci: Data Mining, Algoritma C4.5, Loyalitas Nasabah

Abstrak-C4.5 algorithm is a decision tree algorithm group. This algorithm has input in the form of training samples and samples. While samples are data fields which we will use as parameters in classifying data. From the variable transaction frequency the company can see which customers are loyal to the company based on historical customer transaction data, but there are still some variables that make customers loyal to the company. These variables are age, customer gender, company sales gender, educational background, customer transaction frequency. The company knows how to predict customers who will be loyal to the company based on the experience of some of the variables above, but the company does not know the most influential variable in the assessment of loyal customers because of some of the variables above are not interconnected and it is uncertain if one variable can make a decision whether the customer loyal. Based on the decision tree that has made the most influential attribute on customer loyalty is the educational background because it has the highest gain value of 1.545292721 and as the root of the decision tree while the client's gender does not significantly affect customer loyalty because it is always at the last node with the gain value which is 0.623919119 .

Keywords: Data Mining, C4.5 Algorithm, Customer Loyalty

\section{PENDAhULUAN}

Loyalitas digunakan untuk melukiskan kesediaan pelanggan untuk terus berlangganan pada sebuah perusahaan dalam jangka panjang, dengan membeli dan menggunakan barang dan jasanya secara berulang, lebih baik lagi secara eksklusif, dan dengan suka rela merekomendasikan produk perusahaan tersebut kepada teman-temannya. Ada beberapa variabel yang dapat memprediksi loyalitas nasabah di PT. Erdhika Elit Sekuritas salah satunya adalah frekuensi transaksi, frekuensi transaksi yang dimaksud disini ialah seberapa sering nasabah melakukan transaksi yang berupa jual beli saham melalui broker Erdhika Elit Sekuritas, dari variabel frekuensi transaksi perusahaan dapat melihat nasabah mana yang loyal terhadap perusahaan berdasarkan data historis transaksi nasabah, namun masih ada beberapa variabel yang membuat nasabah loyal terhadap perusahaan. Variabel variabel tersebut ialah gender, usia, sales perusahaan, frekuensi transaksi, top up awal nasabah, dan kapan nasabah pertama kali melakukan transaksi. Variabel tersebut didapat dari wawancara dengan karyawan senior di PT. Erdhika Elit Sekuritas, perusahaan mengetahui bagaimana memprediksi nasabah yang akan loyal terhadap perusahaan berdasarkan pengalaman dari beberapa variabel diatas, namun perusahaan tidak mengetahui variabel yang paling berpengaruh dalam penilaian nasabah yang loyal karena dari beberapa variabel diatas tidak saling terhubung dan belum pasti kalau satu variabel dapat membuat keputusan apakah nasabah tersebut loyal. Tujuan dari penelitian ini diharapkan dapat membentuk model klasifikasi pohon keputusan untuk memprediksi loyalitas nasabah dan melihat variabel mana yang paling berpengaruh.

Menurut [1] "Salah satu faktor yang mempengaruhi loyalitas pelanggan adalah kualitas pelayanan. Kualitas dalam sebuah pelayanan merupakan kondisi dinamis yang berhubungan dengan produk, jasa, manusia, proses, dan lingkungan yang memenuhi atau melebihi harapan. Dengan demikian kepuasan pelanggan akan tercapai apabila kualitas pelayanan yang diberikan sesuai dengan kebutuhan pelanggan. Hal ini diartikan bahwa peningkatan kepuasan pelanggan harus dicapai secara menyeluruh (overall satisfaction), artinya harapan pelanggan secara menyeluruh harus dipuaskan pada tingkat "sangat puas".".

Penelitian yang dilakukan oleh [2] meneliti tentang Kajian Penerapan Metode Klasifikasi Data Mining Algoritma C.45 untuk Prediksi Kelayakan Kredit Pada Bank Mayapada Jakarta. "Menerapkan algoritma C4.5 
untuk meningkatkan keakuratan analisa kredit pada Bank Mayapada Mitra Usaha Cabang PGC dengan hasil akhir yaitu dengan meningkatkan sistem analisa kredit untuk penentuan kelayakan pemberian kredit bagi calon debitur yang akan mengajukan kredit pada Bank Mayapada.”.

Penelitian yang dilakukan oleh [3] meneliti tentang Algoritma C4.5 untuk Memprediksi Pengambilan Keputusan Memilih Deposito Berjangka. "Penelitian ini menggunakan Algoritma Klasifikasi decision tree C4.5 dengan melakukan klasifikasi terhadap kategori yang paling mempengaruhi untuk membuat keputusan ya atau tidak untuk melakukan deposito dengan hasil akhir untuk menentukan keputusan pemilihan deposito berjangka yang dilakukan di sebuah bank.”.

Penelitian yang dilakukan oleh [4] meneliti tentang Implementasi Algoritma C4.5 Terhadap Kepuasan Pelanggan. "Melakukan penggolongan atau klasifikasi terhadap kepuasan pelanggan restoran cepat saji menggunakan knowledge discovery in database dengan hasil akhir terbentuk model kepuasan pelanggan restoran cepat saji, tingkat akurasi data yang hasilkan cukup tinggi dan masuk dalam ketegori sangat baik, model yang diperoleh sudah dapat dijadikan acuan dalam meningkatkan kepuasan pelanggan dan memperbaiki kualitas restoran cepat saji."

Berdasarkan uraian permasalahan tersebut, penelitian ini bertujuan untuk merancang suatu model untuk memprediksi loyalitas nasabah berdasarkan beberapa variabel. Membentuk model klasifikasi pohon keputusan untuk memprediksi loyalitas pelanggan dan menghasilkan variabel yang paling berpengaruh.

\section{METODE PENELITIAN}

\subsection{Tahapan Penelitian}

Metodologi Penelitian merupakan tahap-tahap penelitian yang sistematis untuk membantu penelitian menjadi terarah dengan baik. Berikut adalah metodologi penelitian yang dilakukan.

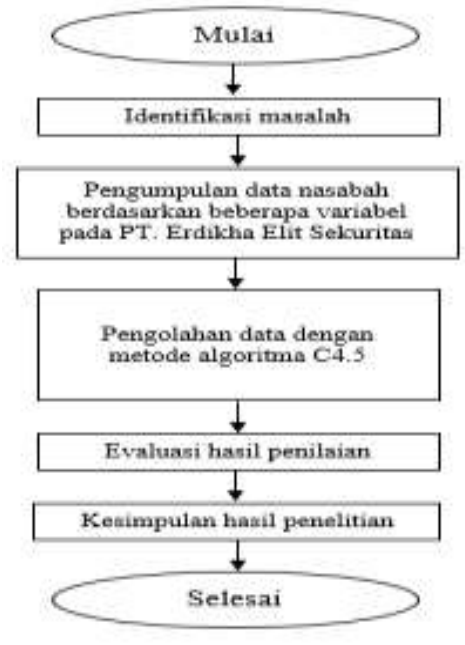

Gambar 1. Tahapan Penelitian

\subsection{Instrumen Penelitian}

Instrumen penelitian merupakan sebuah alat yang digunakan untuk mengumpulkan data atau informasi yang bermanfaat untuk menjawab permasalahan penelitian. Data ataupun informasi penelitian ini diperoleh dari instansi terkait yaitu, data nasabah berdasarkan beberapa variabel dengan jangka waktu 3 tahun terakhir pada PT. Erdikha Elit Sekuritas yang digunakan untuk memprediksi loyalitas nasabah.

\subsection{Teknik Pengumpulan Data}

Metode pengumpulan data yang dilakukan pada penelitian ini yaitu melakukan wawancara terhadap karyawan dengan menanyakan hal - hal yang berkaitan dengan loyalitas nasabah pada PT. Erdikha Elit Sekuritas. Kemudian melakukan pengambilan data mengenai data tentang loyalitas nasabah pada PT. Erdikha Elit Sekuritas sebanyak 3 tahun terakhir.

Selanjutnya penelitian ini juga melakukan pengumpulan informasi mengenai metode ataupun hal yang berhubungan dengan penyusunan penelitian dari jurnal ataupun buku.

\subsection{Klasifikasi}

"Klasifikasi adalah proses menemukan model (fungsi) yang menjelaskan dan membedakan kelas-kelas atau konsep, dengan tujuan agar model yang diperoleh dapat digunakan untuk memprediksikan kelas atau objek yang memiliki label kelas tidak diketahui. Model yang turunkan didasarkan pada analisis dari training data (yaitu 
objek data yang memiliki label kelas yang diketahui). Model yang diturunkan dapat direpresentasikan dalam berbagai bentuk seperti aturan IF-THEN klasifikasi, pohon keputusan, formula matematika atau jaringan syarf tiruan. Dalam banyak kasus, pengguna ingin memprediksikan nilai- nilai data yang tidak tersedia atau hilang (bukan label dari kelas). Dalam kasus ini biasanya nilai data yang akan diprediksi merupakan data numeric. Kasus ini seringkali dirujuk sebagai prediksi. Di samping itu, prediksi lebih menekankan pada identifikasi trend dari distribusi berdasarkan pada data yang tersedia.”, [5].

\subsection{Algoritma C.45}

"Algoritma C4.5 merupakan kelompok algoritma decision tree. Algoritma ini mempunyai input berupa training samples dan samples. Training samples berupa data contoh yang akan digunakan untuk membangun sebuah tree yang telah diuji kebenarannya. Sedangkan samples merupakan field-field data yang nantinya akan kita gunakan sebagai parameter dalam melakukan klasifikasi data.", [6].

Dalam penelitian ini menggunakan analisis data kuantitatif yang merupakan jenis data yang dapat diukur atau dihitung secara langsung sebagai angka atau bilangan. Dalam hal ini menggunakan algoritma C4.5, dengan tahapan sebagai berikut:

a. Pilih atribut sebagai simpul akar.

b. Buat cabang untuk tiap - tiap nilai.

c. Bagi kasus dalam cabang.

d. Ulangi proses untuk setiap cabang sampai semua kasus pada cabang memiliki kelas yang sama.

e. Pemilihan atribut sebagai simpul, baik simpul akar(root) atau simpul internal berdasarkan pada nilai Gain tertinggi dari atribut-atribut yang ada. Perhitungan nilai Gain digunakan rumus sebagai berikut:

$$
\operatorname{Gain}(\mathrm{S}, \mathrm{A})=\operatorname{Entropy}(\mathrm{S})-\sum_{i=0}^{n} \frac{|S i|}{|S|} * \operatorname{Entropy}(\mathrm{Si})
$$

S = Himpunan Kasus.

$\mathrm{A}=$ Atribut.

I = Jumlah Partisi Atribut.

$|\mathrm{Si}|=$ Jumlah Kasus pada partisi ke i.

$|\mathrm{S}|=$ Jumlah Kasus dalam S.

f. Sedangkan penghitungan nilai entropy dapat dilihat pada rumus berikut :

$$
\operatorname{Entropy}(S)=\sum_{i=1}^{n}-p i * \log 2 p i
$$

$\mathrm{S} \quad=$ Himpunan Kasus

$\mathrm{n} \quad=$ Jumlah partisi S

pi $\quad=$ Proporsi dari Si terhadap S

\section{HASIL DAN PEMBAHASAN}

Penelitian ini bertujuan untuk memprediksi variabel yang paling berpengaruh pada loyalitas nasabah PT Erdhika Elit Sekuritas dengan metode algoritma C4.5, dalam menentukan hasil penelitian ini menggunakan data training sebanyak 250 data nasabah.

\subsection{Perhitungan Manual Algoritma C4.5}

Langkah untuk menentukan pohon keputusan dengan menggunakan algoritma C4.5 dengan menggunakan data training sebanyak 250, yaitu:

a. Menyiapkan data training sebanyak data 250 nasabah yang digunakan penelitian ini. Data training biasanya diambil dari data primer yang sebelumnya sudah dikelompokan kedalam kelas-kelas tertentu.

b. Hitung Nilai Entropy, setelah dilakukan perhitungan nilai entropy seperti rumus didapat hasil nilai entrophy sebagai berikut :

$$
\begin{aligned}
& \text { Entropy }(S)=\sum_{i=1}^{n}-p i * \log _{2} p i \\
& =\left(-\frac{125}{250} * \log _{2}\left(\frac{125}{250}\right)\right)+\left(-\frac{125}{250} * \log _{2}\left(\frac{125}{250}\right)\right) \\
& =1
\end{aligned}
$$

c. Setelah itu menghitung nilai gain setiap atribut, lalu pilih gain tertinggi dari setiap atribut untuk dijadikan akar poon keputusan, peritungan nilai gain menggunakan rumus.

$$
\begin{aligned}
& =(1)-\left(\frac{144}{250}\right) *(0,998747298)+\left(\frac{106}{250}\right) *(0,997687576) \\
& =0,847741089 .
\end{aligned}
$$

\subsection{Perhitungan Entropy dan Gain}

Proses perhitungan node akar (root) 
JURNAL MEDIA INFORMATIKA BUDIDARMA

Volume 4, Nomor 1, Januari 2020, Page 65-71

ISSN 2614-5278 (media cetak), ISSN 2548-8368 (media online)

Available Online at https://ejurnal.stmik-budidarma.ac.id/index.php/mib

DOI $10.30865 /$ mib.v4i1.1652

Perhitungan semua atribut dilakukan untuk mendapatkan nilai gain tertinggi. Hasil perhitungan seluruh atribut pada tabel 1 dibawah ini adalah proses untuk pembentukan pohon keputusan (decision tree) dengan menggunkan metode algoritma C4.5.

Tabel 1. Hasil Perhitungan Entropy dan Gain Node Akar

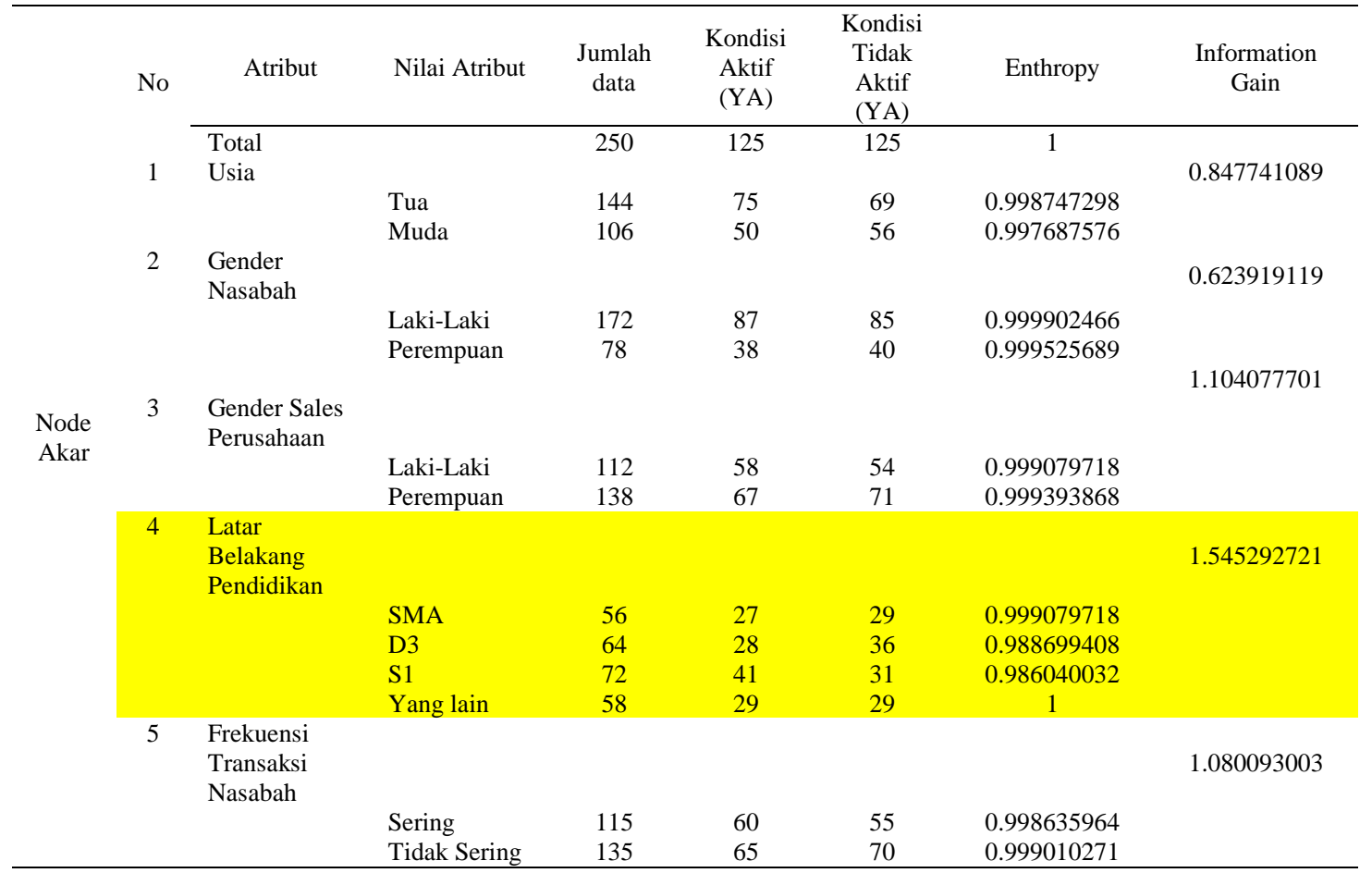

Dari hasil tabel 1. setelah dihitung nilai gain setiap atribut, maka hasilnya adalah atribut " latar belakang pendidikan " yang bmendapat nilai gain tertinggi dengan hasil 1,545292721. Maka " latar belakang pendidikan " menjadi node akar (root). Kemudian pada atribut " latar belakang pendidikan " memiliki nilai atribut "SMA ", " D3 “, “ S1 “, dan " Yang Lain “ menjadi daun (leaf). Dapat dilihat dari gambar pohon keputusan dibawah ini.

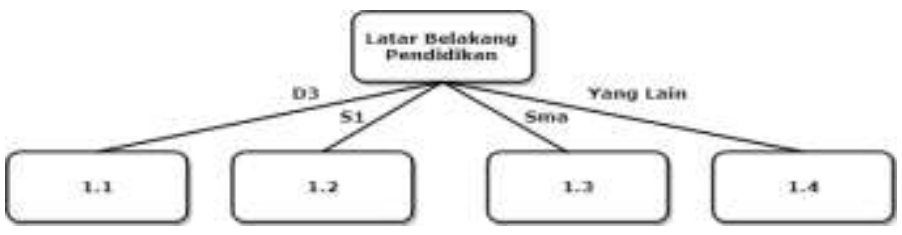

Gambar 2 Pohon Keputusan Node Akar

Berdasarkan pohon keputusan node akar, nilai atribut D3, S1, Sma, Yang Lain belum memiliki keputusan. Maka selanjutnya akan menentukan simpul berikutnya, yaitu simpul 1.1, 1.2, 1.3, dan, 1.4. kemudian menghitung entrophy dan gain pada setiap nilai atribut.

Proses perhitungan node 1.1 nilai atribut D3

Tabel 2. Hasil Perhitungan Entropy dan Gain Node 1.1

\begin{tabular}{|c|c|c|c|c|c|c|c|c|}
\hline \multirow{12}{*}{$\begin{array}{c}\text { Node } \\
1.1\end{array}$} & No & Atribut & Nilai Atribut & $\begin{array}{c}\text { Jumlah } \\
\text { data }\end{array}$ & $\begin{array}{c}\text { Kondisi } \\
\text { Aktif } \\
\text { (YA) }\end{array}$ & $\begin{array}{c}\text { Kondisi } \\
\text { Tidak } \\
\text { Aktif } \\
\text { (YA) }\end{array}$ & Enthropy & $\begin{array}{c}\text { Information } \\
\text { Gain }\end{array}$ \\
\hline & \multirow{3}{*}{1} & \multirow{4}{*}{$\begin{array}{l}\text { Total } \\
\text { Usia }\end{array}$} & & 64 & 28 & 36 & 0.988699408 & \multirow{4}{*}{0.747849062} \\
\hline & & & & & & & & \\
\hline & & & Tua & 39 & 19 & 20 & 0.999525689 & \\
\hline & \multirow[b]{2}{*}{2} & & Muda & 25 & 9 & 16 & 0.942683189 & \\
\hline & & $\begin{array}{l}\text { Gender } \\
\text { Nasabah }\end{array}$ & & & & & & 0.538831093 \\
\hline & \multirow{5}{*}{3} & & Laki-Laki & 47 & 19 & 28 & 0.973385435 & \multirow{5}{*}{1.056458356} \\
\hline & & & Perempuan & 17 & 9 & 8 & 0.997502546 & \\
\hline & & $\begin{array}{l}\text { Gender Sales } \\
\text { Perusahaan }\end{array}$ & & & & & & \\
\hline & & & Laki-Laki & 29 & 15 & 14 & 0.999142104 & \\
\hline & & & Perempuan & & & & 0.951762676 & \\
\hline & 4 & Frekuensi & & & & & & 1.305142061 \\
\hline
\end{tabular}


Available Online at https://ejurnal.stmik-budidarma.ac.id/index.php/mib DOI $10.30865 /$ mib.v4i1.1652

\begin{tabular}{llcccc}
\hline Transaksi & & & & & \\
Nasabah & & & & & \\
& Sering & 22 & 9 & 13 & 0.976020648 \\
& Tidak Sering & 42 & 19 & 23 & 0.993447238 \\
\hline
\end{tabular}

Dari hasil tabel 2 setelah dihitung nilai gain setiap atribut, maka hasilnya adalah atribut " frekuensi transaksi nasabah " yang mendapat nilai gain tertinggi dengan hasil 1,305142061, pada atribut frekuensi transaksi nasabah memiliki nilai atribut " sering " dan " tidak Sering ", dapat dilihat dari pohon keputusan di bawah ini.

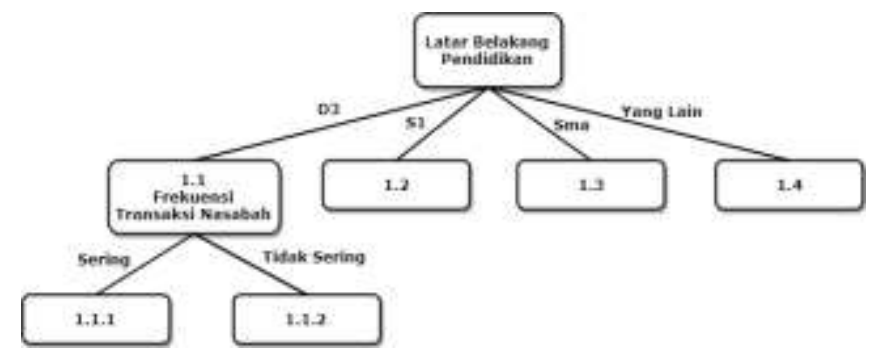

Gambar 3. Pohon Keputusan Node 1.1

Berdasarkan pembentukan pohon keputusan node 1.1 frekuensi transaksi nasabah tidak memiliki daun atau leaf. Proses perhitungan node 1.2 nilai atribut $\mathrm{S} 1$

Tabel 3. Hasil Perhitungan Entropy dan Gain Node 1.2

\begin{tabular}{|c|c|c|c|c|c|c|c|c|}
\hline \multirow{14}{*}{$\begin{array}{c}\text { Node } \\
1.2\end{array}$} & No & Atribut & Nilai Atribut & $\begin{array}{c}\text { Jumlah } \\
\text { data }\end{array}$ & $\begin{array}{l}\text { Kondisi } \\
\text { Aktif } \\
\text { (YA) }\end{array}$ & $\begin{array}{c}\text { Kondisi } \\
\text { Tidak } \\
\text { Aktif } \\
\text { (YA) }\end{array}$ & Enthropy & $\begin{array}{c}\text { Information } \\
\text { Gain }\end{array}$ \\
\hline & & Total & & 72 & 41 & 31 & 0.986040032 & \multirow{4}{*}{0.901527416} \\
\hline & 1 & Usia & & & & & & \\
\hline & \multirow{5}{*}{2} & & Tua & 39 & 22 & 17 & 0.988110837 & \\
\hline & & & Muda & 33 & 19 & 14 & 0.98337619 & \\
\hline & & $\begin{array}{l}\text { Gender } \\
\text { Nasabah }\end{array}$ & & & & & & \multirow[t]{3}{*}{0.617324341} \\
\hline & & & Laki-Laki & 50 & 30 & 20 & 0.970950594 & \\
\hline & & & Perempuan & 22 & 11 & 11 & 1 & \\
\hline & \multirow[t]{3}{*}{3} & $\begin{array}{l}\text { Gender Sales } \\
\text { Perusahaan }\end{array}$ & & & & & & \multirow[t]{3}{*}{1.061775441} \\
\hline & & & Laki-Laki & 32 & 15 & 17 & 0.997180399 & \\
\hline & & & Perempuan & 40 & 26 & 14 & 0.934068055 & \\
\hline & \multirow[t]{3}{*}{4} & $\begin{array}{l}\text { Frekuensi } \\
\text { Transaksi } \\
\text { Nasabah }\end{array}$ & & & & & & \multirow[t]{3}{*}{0.935084364} \\
\hline & & & Sering & 37 & 19 & 18 & 0.99947302 & \\
\hline & & & Tidak Sering & 35 & 22 & 13 & 0.951762676 & \\
\hline
\end{tabular}

Dari hasil tabel 3 setelah dihitung nilai gain setiap atribut, maka hasilnya adalah atribut " gender sales perusahaan " yang mendapat nilai gain tertinggi dengan hasil 1,061775441, pada atribut gender sales perusahaan memiliki nilai atribut " laki-laki " dan " perempuan ", dapat dilihat dari pohon keputusan di bawah ini.

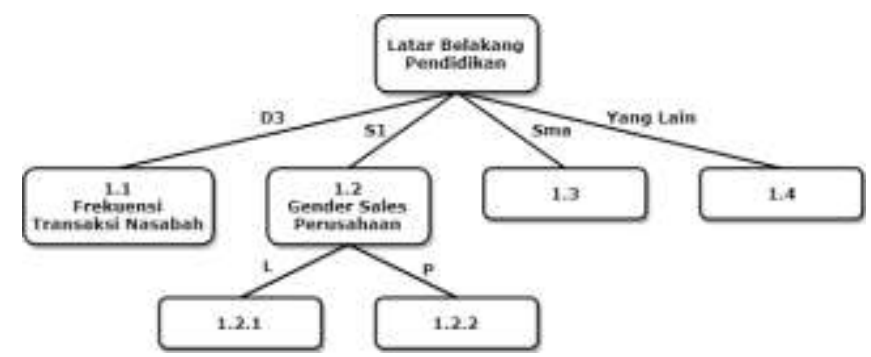

Gambar 4. Pohon Keputusan Node 1.2

Berdasarkan pembentukan pohon keputusan node 1.2 Gender Sales Perusahaan tidak memiliki daun atau leaf. Proses perhitungan node 1.3

Tabel 4. Hasil Perhitungan Entropy dan Gain Node 1.3

\begin{tabular}{|c|c|c|c|c|c|c|c|c|}
\hline \multirow{4}{*}{$\begin{array}{c}\text { Node } \\
1.3\end{array}$} & No & Atribut & Nilai Atribut & $\begin{array}{c}\text { Jumlah } \\
\text { data }\end{array}$ & $\begin{array}{c}\text { Kondisi } \\
\text { Aktif } \\
\text { (YA) }\end{array}$ & $\begin{array}{c}\text { Kondisi } \\
\text { Tidak } \\
\text { Aktif } \\
\text { (YA) }\end{array}$ & Enthropy & $\begin{array}{c}\text { Information } \\
\text { Gain }\end{array}$ \\
\hline & \multirow{3}{*}{1} & \multirow{3}{*}{$\begin{array}{l}\text { Total } \\
\text { Usia }\end{array}$} & & 56 & 27 & 29 & 0.999079718 & \multirow{3}{*}{0.639068452} \\
\hline & & & & & & & & \\
\hline & & & Tua & 38 & 19 & 19 & 1 & \\
\hline
\end{tabular}


Available Online at https://ejurnal.stmik-budidarma.ac.id/index.php/mib DOI $10.30865 /$ mib.v4i1.1652

\begin{tabular}{|c|c|c|c|c|c|c|c|}
\hline 2 & $\begin{array}{l}\text { Gender } \\
\text { Nasabah }\end{array}$ & Muda & 18 & 8 & 10 & 0.99107606 & 0.639068452 \\
\hline & & $\begin{array}{l}\text { Laki-Laki } \\
\text { Perempuan }\end{array}$ & $\begin{array}{l}38 \\
18\end{array}$ & $\begin{array}{c}19 \\
8\end{array}$ & $\begin{array}{l}19 \\
10\end{array}$ & $\begin{array}{c}1 \\
0.99107606\end{array}$ & \\
\hline 3 & $\begin{array}{l}\text { Gender Sales } \\
\text { Perusahaan }\end{array}$ & $\begin{array}{l}\text { Laki-Laki } \\
\text { Perempuan }\end{array}$ & $\begin{array}{l}23 \\
33\end{array}$ & $\begin{array}{l}12 \\
15\end{array}$ & $\begin{array}{l}11 \\
18\end{array}$ & $\begin{array}{l}0.998635964 \\
0.994030211\end{array}$ & 1.174693465 \\
\hline 4 & $\begin{array}{l}\text { Frekuensi } \\
\text { Transaksi } \\
\text { Nasabah }\end{array}$ & $\begin{array}{l}\text { Sering } \\
\text { Tidak Sering }\end{array}$ & $\begin{array}{l}30 \\
26\end{array}$ & $\begin{array}{c}20 \\
7\end{array}$ & $\begin{array}{l}10 \\
19\end{array}$ & $\begin{array}{l}0.918295834 \\
0.840358672\end{array}$ & 0.897302047 \\
\hline
\end{tabular}

Dari hasil tabel 4 setelah dihitung nilai gain setiap atribut, maka hasilnya adalah atribut " gender sales perusahaan " yang mendapat nilai gain tertinggi dengan hasil 1,174693465, pada atribut gender sales perusahaan memiliki nilai atribut " laki-laki " dan " perempuan ", dapat dilihat dari pohon keputusan di bawah ini.

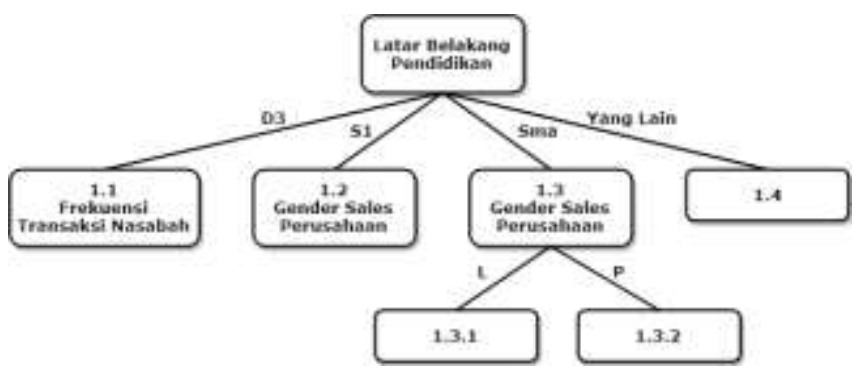

Gambar 5. Pohon Keputusan Node 1.3

Berdasarkan pembentukan pohon keputusan node 1.3 gender sales perusahaan tidak memiliki daun atau leaf. Proses perhitungan 1.4

Tabel 5. Hasil Perhitungan Entropy dan Gain Node 1.4

\begin{tabular}{|c|c|c|c|c|c|c|c|c|}
\hline \multirow{14}{*}{$\begin{array}{c}\text { Node } \\
1.4\end{array}$} & No & Atribut & Nilai Atribut & $\begin{array}{c}\text { Jumlah } \\
\text { data }\end{array}$ & $\begin{array}{c}\text { Kondisi } \\
\text { Aktif } \\
\text { (YA) }\end{array}$ & $\begin{array}{c}\text { Kondisi } \\
\text { Tidak } \\
\text { Aktif } \\
\text { (YA) } \\
\end{array}$ & Enthropy & $\begin{array}{c}\text { Information } \\
\text { Gain }\end{array}$ \\
\hline & & Total & & 58 & 29 & 29 & 1 & \multirow{4}{*}{1.03460149} \\
\hline & 1 & Usia & & & & & & \\
\hline & \multirow{5}{*}{2} & & Tua & 28 & 15 & 13 & 0.99631652 & \\
\hline & & & Muda & 30 & 14 & 16 & 0.996791632 & \\
\hline & & $\begin{array}{l}\text { Gender } \\
\text { Nasabah }\end{array}$ & & & & & & \multirow[t]{3}{*}{0.723881644} \\
\hline & & & Laki-Laki & 37 & 19 & 18 & 0.99947302 & \\
\hline & & & Perempuan & 21 & 10 & 11 & 0.998363673 & \\
\hline & \multirow[t]{3}{*}{3} & $\begin{array}{l}\text { Gender Sales } \\
\text { Perusahaan }\end{array}$ & & & & & & \multirow[t]{3}{*}{1.034961128} \\
\hline & & & Laki-Laki & 28 & 16 & 12 & 0.985228136 & \\
\hline & & & Perempuan & 30 & 13 & 17 & 0.987137774 & \\
\hline & \multirow[t]{3}{*}{4} & $\begin{array}{l}\text { Frekuensi } \\
\text { Transaksi } \\
\text { Nasabah }\end{array}$ & & & & & & \multirow[t]{3}{*}{1.103807914} \\
\hline & & & Sering & 26 & 12 & 14 & 0.995727452 & \\
\hline & & & Tidak Sering & 32 & 17 & 15 & 0.997180399 & \\
\hline
\end{tabular}

Dari hasil tabel 5 setelah dihitung nilai gain setiap atribut, maka hasilnya adalah atribut " frekuensi transaksi nasabah " yang mendapat nilai gain tertinggi dengan hasil 1,103807914, pada frekuensi transaksi nasabah memiliki nilai atribut " sering " dan " tidak sering ", dapat dilihat dari pohon keputusan di bawah ini.

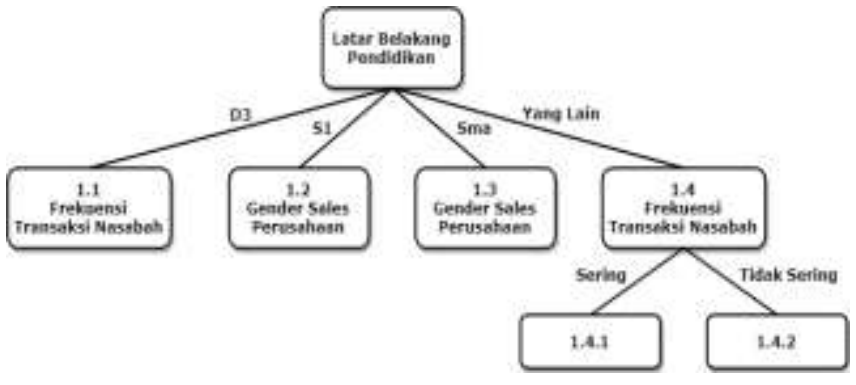

Gambar 6. Pohon Keputusan Node 1.4 
JURNAL MEDIA INFORMATIKA BUDIDARMA

Volume 4, Nomor 1, Januari 2020, Page 65-71

ISSN 2614-5278 (media cetak), ISSN 2548-8368 (media online)

Available Online at https://ejurnal.stmik-budidarma.ac.id/index.php/mib

DOI $10.30865 /$ mib.v4i1.1652

Berdasarkan pembentukan pohon keputusan node 1.4 frekuensi transaksi nasabah tidak memiliki daun atau leaf.

\section{KESIMPULAN}

Dari hasil penelitian yang telah dilakukan, maka kesimpulan dari penelitian ini adalah :

a. Berdasarkan pohon keputusan yang telah dibuat atribut yang paling berpengaruh terhadap loyalitas nasabah adalah Latar Belakang Pendidikan karena memiliki nilai gain yang paling tinggi diantara atribut yang lain dengan nilai gain 1.545292721 dan sebagai akar dari pohon keputusan, sedangkan gender nasabah tidak terlalu berpengaruh terhadap loyalitas nasabah karena selalu berada pada node terakhir dengan nilai gain 0,623919119 .

b. Dalam pengujian dengan menggunakan RapidMiner menghasilkan hasil yang berbeda dengan pengujian yang di lakukan oleh peneliti karena pada RapidMiner tidak menghitung entrophy sampai 0.

Penelitian yang dilakukaan peneliti masih jauh dari sempurna, untuk penelitian selanjutnya maka disarankan hal

- hal sebagai berikut :

a. Untuk mendapatkan hasil yang lebih baik lagi, perlu dilakukan perhitungan dengan menggunakan beberapa teknik data mining lainnya, karena pada penelitian ini penulis hanya menggunakan salah satu teknik data mining yaitu decision tree.

b. Perlu adanya perbandingan terhadap software aplikasi data mining lainnya, karena pada penelitian ini penulis hanya menggunakan software data mining RapidMiner.

\section{REFERENCES}

[1] Y. Ernawati, Y. D. Suseno, and Sunarso, "Pengaruh kualitas produk dan kualitas layanan terhadap loyalitas pelanggan dengan kepuasan pelanggan sebagai variabel mediasi (survei pada pelanggan dgc coffeeshop di solo, kuoarjo,sragen)," J. Manaj. Sumber Daya Mns., vol. 11, no. 2, pp. 175-187, 2017.

[2] N. Iriadi and N. Nuraeni, "Kajian Penerapan Metode Klasifikasi Data Mining Algoritma C4.5 untuk Prediksi Kelayakan Kredit Pada Bank Mayapada Jakarta,” Tek. Komput. AMIK BSI, vol. II, pp. 132-137, 2016.

[3] H. M. Nawawi, S. Rahayu, M. ja'far Shidiq, and J. J. Purnama, "Algoritma C4.5 untuk Memprediksi Pengambilan Keputusan Memilih Deposito Berjangka," vol. 16, no. 1, pp. 65-72, 2019.

[4] H. D. Tarigan, F. Destiawati, and A. Fitriansyah, "Implementasi Algoritma C4.5 Terhadap Kepuasan Pelanggan," Ethos (Jurnal Penelit. dan Pengabdi. Masyarakat), vol. Vol. 6, No, pp. 80-86, 2017.

[5] K. J. Atmaja, I. B. G. Anandita, and N. K. C. Dewi, "Penerapan Data Mining Untuk Memprediksi Potensi Pendonor Darah Menjadi Pendonor Tetap Metode Decision Tree C.45,” $s @ C I E S$, vol. 7, pp. 101-108, 2017.

[6] Ihsan and R. Wajhillah, "Penerapan Algoritma C4.5 Terhadap Diagnosa Penyakit Demam Tifoid Berbasis Mobile," SWABUMI, no. October 2015, 2015. 